Maciej DRZONEK

DOI : $10.14746 / \mathrm{pp} .2020 .25 .2 .7$

Uniwersytet Szczeciński

ORCID ID: 0000-0002-7840-1301

\title{
Władza lokalna nie dla partii? Przypadek Pawła Adamowicza w rywalizacji 2018 roku
}

\begin{abstract}
Streszczenie: Przedmiotem badań podjętych w artykule jest rywalizacja o władzę lokalną w Gdańsku w 2018 r. Cztery wcześniejsze elekcje lat 2002-2014 w rywalizacji o prezydenturę miasta wygrywał Paweł Adamowicz, który zawsze oficjalnie reprezentował bardzo popularną w Gdańsku partię polityczną - PO. W 2018 r. Adamowicz wystartował jednak z własnego komitetu (KWW Pawła Adamowicza Wszystko dla Gdańska) i konkurował o fotel prezydenta miasta zarówno z kandydatem PO (Jarosław Wałęsa), jak i pretendentem PiS (Kacper Płażyński). Wybory z 2018 r. w Gdańsku były zatem interesującym casusem: do walki przystąpił „ten sam” Paweł Adamowicz, ale już jako reprezentant własnego, pozapartyjnego komitetu wyborczego, co więcej, wystąpił przeciwko partii, którą dotychczas zawsze reprezentował. Był to więc ciekawy przypadek do poszukiwania odpowiedzi na pytanie co w tej rywalizacji stanie się elementem przeważającym: jej upartyjnienie czy personalizacja? Po drugie frapujące było sprawdzenie czy przenoszenie dominującego podziału ogólnopolskiego (dawny podział my-oni, a w wersji z 2018 r.: anty-PiS vs. PiS) przynosi partiom politycznym efektywność w rywalizacji o władzę lokalną? Poczyniono następujące założenia: a) opcja personalna jest ważniejsza w rywalizacji o władzę lokalną od sympatii partyjnych; b) nowa wersja podziału „my-oni” (PiS-antyPiS) nie przynosi efektywności w walce o władzę na miejskiej scenie politycznej. Wartością badań jest wykorzystanie w nich nie tylko źródeł publikowanych, ale również niepublikowanych badań jakościowych - anonimowych wywiadów z lokalnymi politykami.
\end{abstract}

Słowa kluczowe: władza lokalna, partie polityczne, personalizacja wyborów lokalnych, Paweł Adamowicz, rywalizacja polityczna, Gdańsk

\section{Wprowadzenie}

$\mathbf{W}$ Gdańsku, cztery kolejne elekcje lat 2002-2014 w rywalizacji o prezydenturę miasta wygrywał Paweł Adamowicz, który każdorazowo oficjalnie reprezentował PO. Warto podkreślić, że w tych latach, wśród miast wojewódzkich to jedyny przypadek, aby wielokadencyjny prezydent zawsze kandydował jako oficjalny reprezentant jednej, tej samej partii politycznej. Co więcej, nawet wśród 66 miast na prawach powiatu casus reelekcji partyjnego prezydenta pojawiał się tylko w jeszcze jednym, innym mieście (w Świnoujściu prezydent Janusz Żmurkiewicz w latach 2002-2014 zawsze rywalizował jako kandydat SLD lub koalicji współtworzonych przez to ugrupowanie).

W 2018 r. Adamowicz wystartował jednak z własnego komitetu (KWW Pawła Adamowicza Wszystko dla Gdańska) i nie tylko nie uzyskał poparcia PO, ale konkurował o fotel prezydenta miasta zarówno z kandydatem tej partii (Jarosław Wałęsa), jak i pretendentem PiS (Kacper Płażyński). We wcześniejszych wyborach (2002-2014) głównymi rywalami P. Adamowicza zawsze okazywali się pretendenci najważniejszych parlamentarnych partii politycznych: w 2002 r. Marek Formela (SLD), a potem trzykrotnie 
Andrzej Jaworski (zawsze jako kandydat PiS). Wybory z 2018 r. w Gdańsku były zatem interesującym casusem: do walki przystąpił ,ten sam” Paweł Adamowicz, ale już jako reprezentant własnego, pozapartyjnego komitetu wyborczego, co więcej, wystąpił przecież przeciwko partii, którą dotychczas zawsze reprezentował. Przypadek gdańskiej rywalizacji z 2018 r. może zatem potwierdzać tezę, że popularny inkumbent zakładając pozapartyjny komitet wyborczy ma szansę na zwycięskie starcie nawet ze sprawnie działającą, parlamentarną partią polityczną.

W Gdańsku do wyborów z 2018 r. wszystko przebiegało wedle pewnych, utartych w latach 2002-2014 schematów: w rywalizacji o fotel włodarza miasta zwyciężał polityk, który afirmował się afiliacją z Platformą Obywatelską. Przed wyborami z 2018 r. zaszły jednak dwie znaczące zmiany, które mogły wpłynąć na wyniki gdańskiej rywalizacji samorządowej: od 2015 r. rządziło w Polsce Prawo i Sprawiedliwość, które cieszyło się w skali ogólnopolskiej wysokim poparciem społecznym. Politycy tej partii byli więc zainteresowani sukcesem w wyborach lokalnych, licząc na to, że ogólnopolskie poparcie dla tej formacji pozytywnie przełoży się na rezultaty w starciu o władzę lokalną. Po drugie, długoletni prezydent Gdańska startujący dotąd z legitymacją PO postanowił zawalczyć o prezydenturę nie tylko poza Platformą, ale również w konfrontacji z kandydatem tej partii.

Tak więc u progu walki wyborczej z 2018 r., w kontekście możliwości zweryfikowania tytułowej hipotezy stolica województwa pomorskiego jawiła się jako ciekawy przypadek do obserwacji co w tej rywalizacji stanie się elementem przeważającym: jej upartyjnienie czy personalizacja? W kontekście perturbacji na miejskiej scenie politycznej Gdańska interesujące było sprawdzenie czy w wyborach prezydenta miasta opcja personalna jest istotniejsza od opcji partyjnej, nawet gdy dotychczasowy przedstawiciel opcji partyjnej staje się konkurentem dla własnej partii? Również specyfika gdańskiej sceny politycznej powodowała, że frapujące byłoby sprawdzenie czy przenoszenie dominującego podziału ogólnopolskiego (dawny podział my-oni, a w wersji z 2018 r.: anty-PiS vs. PiS) przynosi partiom politycznym efektywność w rywalizacji o władzę lokalną? Można bowiem na wstępie poczynić dwa założenia: primo - opcja personalna jest ważniejsza w rywalizacji o władzę lokalną od sympatii partyjnych; secundo - nowa wersja podziału „my-oni” (PiS-antyPiS) nie przynosi efektywności w walce o władzę na miejskiej scenie politycznej.

Do znalezienia odpowiedzi na powyższe pytania oraz zweryfikowania poczynionych hipotez zostaną wykorzystane publikowane dane na temat rywalizacji wyborczej w badanym mieście, a także niepublikowane wyniki badań własnych. W pierwszej grupie źródeł znajdą się materiały publikowane przez Państwową Komisję Wyborczą (zarówno wyniki wyborów lokalnych, jak i parlamentarnych uzyskiwane przez ugrupowania w nich startujące w Gdańsku), wyniki sondaży preferencji politycznych mieszkańców Gdańska w 2018 r. oraz materiały informacyjne dotyczące wyborów samorządowych publikowane w mediach, zwłaszcza tych związanych z Gdańskiem. W grupie źródeł niepublikowanych znajdą się niektóre wyniki prowadzonych badań na temat postrzegania władzy przez polityków lokalnych w miastach na prawach powiatu. Badania te - anonimowe wywiady pogłębione $\mathrm{z}$ respondentami - w trzech miastach trójmiasta przeprowadzano jesienią $2018 \mathrm{r}$. (już po elekcji samorządowej, ale przed tragiczną śmiercią P. Adamowicza) ${ }^{1}$.

${ }^{1}$ Niniejsze rozważania zostały w części przygotowane na podstawie książki: Maciej Drzonek, Wieczni prezydenci. Dwa przypadki trójmiejskie, Ośrodek Myśli Politycznej, Kraków 2019. 
Zagadnienia związane z upartyjnieniem i personalizacją na polu polityki lokalnej, jak również w odniesieniu do problemu elekcji ogólnokrajowych były przedmiotem zainteresowania wielu politologów i socjologów. Wiesław Bartkowski wskazywał, że zachowania wyborcze można interpretować w powiązaniu do dwóch punktów odniesienia: przestrzennej teorii wyborów oraz teorii identyfikacji partyjnej (Bartkowski, 2003, s. 113-121). Dominik Szczepański zauważał, że przeciwstawnymi czynnikami wyjaśniającymi zachowania wyborcze są upartyjnienie oraz personalizacja, ponieważ ten pierwszy może „całkowicie pomijać identyfikację wyborców z politykami” (Szczepański, 2016, s. 78). Jak przypomnieli Paweł Antkowiak i Łukasz Scheffs, zjawiskiem personalizacji w polityce jako jeden z pierwszych zajmował się w USA Martin P. Wattenberg, który badania na ten temat prowadził w latach 80. XX w. (Antkowiak, Scheffs, 2015, s. 122-123), koncentrując się na kampaniach w wyborach prezydenckich (Wattenberg, 1991). Istotne ustalenia dotyczące tych zagadnień poczyniło wielu innych autorów, wśród których warto wspomnieć choćby o T. Poguntke i P. Webbie (Poguntke, Webb, 2005). Wypada także wymienić takich autorów jak: P. Delwit, J.-B. Pilet, H. Reynaert, K. Steyvers (Delwit, Pilet, Reynaert, Steyvers, 2005). W odniesieniu do wyborów lokalnych interesujące wnioski zawierały prace dotyczące tej problematyki, a odnoszone do niektórych krajów skandynawskich (Elmelund-Præstekær, Kjaer, 2013; Jacobsen, Skollevold, 2016).

W literaturze zagranicznej, podejmując zagadnienia personalizacji i prezydencjalizacji, niekiedy zwracano uwagę, iż terminy te nie do końca są tożsame i raczej nie powinny być stosowane synonimicznie. Jako egzemplifikację takiego podejścia można przytoczyć ustalenia poczynione przez Paolo Manciniego, który w sposób konsekwentny i przekonujący dokonał rozróżnienia trzech podobnych pojęć. Wedle interpretacji włoskiego socjologa prezydencjalizacja jest terminem odnoszącym się do personalizacji ról instytucjonalnych. Kategoria „lideryzacji” (ang. liderization) odnosi się natomiast do personalizacji głównych stanowisk w ramach organizacji partyjnych. Z kolei pojęcie „personalizacji” sensu stricte pozostaje w relacji do skoncentrowania się wyborców na pojedynczym kandydacie podczas podejmowania decyzji wyborczej (Mancini, 2011, s. 52). Niektórzy autorzy podejmujący tę kwestię w literaturze polskiej uważają jednak, że terminy prezydencjalizacji i personalizacji można używać zamiennie (Peszyński, 2016, s. 38; Peszyński, 2012, s. 204-205; Kowalczyk, 2014, s. 44). Nie rozstrzygając w tym miejscu, które stanowisko jest bardziej zasadne warto odnotować, iż dość zgodnie personalizacja oraz upartyjnienie są kategoriami pojęciowymi wykorzystywanymi do wyjaśniania decyzji podejmowanych przez wyborców podczas elekcji. Zatem próbując wyjaśnić dlaczego wyborcy głosują na konkretne osoby można odpowiedzi poszukiwać odwołując się do uzasadnienia personalistycznego (przyczyną są osobiste cechy wybieranych kandydatów) albo do wyttumaczenia instytucjonalnego (partyjnego) - wyborcy podejmując decyzje wyborcze kierują się sympatiami partyjnymi a nie personalnymi.

W kontekście badań dotyczących upartyjnienia i personalizacji rywalizacji wyborczej na poziomie lokalnym warto wspomnieć o interesujących pracach Jarosława Flisa i Adama Gendźwiłła oraz współpracujących z nimi badaczy (Bukowski, Flis, Hess, Szymańska, 2011; Gendźwiłł, Żółtak, 2014, s. 1122-1145; Flis, Gendźwiłł, Stolicki, 2018, s. 33-64; Gendźwiłł, 2013, s. 467-486), a także o innych publikacjach (Drzonek, 2014; Drzonek, 2016). 
W pracach tych szeroko podejmowano kwestię upartyjnienia - pojęcie to generalnie nie wzbudza rozbieżności interpretacyjnych. Biorąc pod uwagę ograniczoną ilość miejsca w niniejszych rozważaniach, wypada jedynie wskazać, iż upartyjnienie w rywalizacji wyborczej rozumiane będzie po pierwsze, jako kierowanie się przez wyborców czynnikami instytucjonalnymi, afiliacją partyjną wybieranych kandydatów, aniżeli ich cechami personalnymi. Po drugie, co oczywiste, ale warte podkreślenia, zjawisku upartyjnienia towarzyszy intencjonalne auto-eksponowanie się partii politycznych w procesie wyborczym. Innymi słowy, w tym przypadku partie wystawiają pretendentów do prezydentury jako kandydatów oficjalnych komitetów partyjnych, a nie tzw. aktorów niby-bezpartyjnych (szerzej zob. np. Drzonek, 2019b, s. 127).

Jak zauważali niektórzy wyżej wspomniani autorzy, upartyjnienie z reguły występuje w wyborach lokalnych w większych miastach, a także generalnie w elekcjach do sejmików (Bukowski, Flis, Hess, Szymańska, 2011, s. 18). Badanie dotyczące alternacji i reelekcji prezydentów 19 miast na prawach powiatu (wszystkie o statusie wojewódzkim, plus Gdynia) pokazało jednakowoż, że afiliacje partyjne wyraźnie wspomagały pretendentów podczas pierwotnych elekcji w $2002 \mathrm{r}$. oraz przy alternacji władzy w wyborach 2006-2018. Innymi słowy upartyjnienie kandydata do fotela prezydenta miasta okazywało się pomocne $\mathrm{w}$ pokonaniu inkumbenta. $\mathrm{Z}$ kolei $\mathrm{w}$ miastach, $\mathrm{w}$ których odbywały się reelekcje (60 przypadków na 95 z lat 2002-2018 w badanych 19. miastach) zaobserwowano, iż inkumbenci zdecydowanie częściej nie posiadali afiliacji partyjnej (Drzonek, 2019a, s. 136-137). Stąd, choć samo rozumienie pojęcia upartyjnienia nie wzbudza dużych wątpliwości, to fakt jego pojawiania się w konkretnych wyborach wcale nie jest taki oczywisty. Jak wspomniano, Gdańsk jest w tym właśnie kontekście niezwykle frapującym przypadkiem - w latach 2002-2014 czterokrotnie fotel prezydenta zdobywał P. Adamowicz jako pretendent silnej partii politycznej, a w elekcji 2018 r. zerwał z tą partyjną afiliacją.

\section{Pozycja partii politycznych w Gdańsku}

Aby zobrazować pozycję polityczną głównych ugrupowań parlamentarnych w Gdańsku przygotowano zestawienie ich wyników wyborczych w kolejnych sześciu elekcjach w latach 2001-2019 (tabela 1).

W Gdańsku PO w każdych wyborach parlamentarnych osiągała znacząco lepsze rezultaty, tak w stosunku do własnych rezultatów w skali ogólnopolskiej, jak i w odniesieniu do wyników PiS. Z powyższego zestawienia wynika, iż formacja, której twarzą stał się D. Tusk otrzymywała o co najmniej $13 \mathrm{pp}$. lepsze notowania (2015) od wyników w Polsce (w 2005 r. różnica ta wyniosła 22 pp., a w 2019 r. - prawie 23 pp.). Z kolei notowania PiS były zawsze wyraźnie niższe od tych otrzymywanych przez PO. Nawet w wyborach z lat 2015 i 2019, które partia Jarosława Kaczyńskiego przecież wygrywała, w Gdańsku PiS otrzymał poparcie niższe od PO, odpowiednio o 9,83 pp. i o 25,03 pp. Przewaga PO nad PiS była widoczna zwłaszcza w latach 2007 i 2011 (rezultaty lepsze o ponad 30 pp.), a także w 2005 r. kiedy wynosiła 19,88 pp. 
Tabela 1

Wyniki wyborcze w Gdańsku czterech głównych ugrupowań parlamentarnych, które w wyborach do Sejmu w latach 2001-2019 przynajmniej pięciokrotnie miały swoją reprezentację poselską. SLD startowało w ramach komitetów o różnych nazwach:

KKW SLD-UP (2001), KKW Lewica i Demokraci (2007), KW SLD (2011, 2019),

KKW Zjednoczona Lewica (2015). PO w 2019 r. startowała w ramach KKW Koalicja Obywatelska PO .N IPL Zieloni.

Wartości kursywą dotyczą wyników danej partii w skali ogólnopolskiej

\begin{tabular}{|l|l|r|r|r|r|r|r||}
\hline \hline Partia & & $\mathbf{2 0 0 1}$ & $\mathbf{2 0 0 5}$ & $\mathbf{2 0 0 7}$ & $\mathbf{2 0 1 1}$ & $\mathbf{2 0 1 5}$ & $\mathbf{2 0 1 9}$ \\
\hline \multirow{2}{*}{ PiS } & Gdańsk & 20,01 & 26,26 & 26,61 & 24,53 & 28,09 & 25,08 \\
\cline { 2 - 8 } & Polska & 9,50 & 26,99 & 32,11 & 29,89 & 37,58 & 43,59 \\
\hline \multirow{2}{*}{ PO } & Gdańsk & 31,45 & 46,14 & 59,65 & 57,24 & 37,92 & 50,11 \\
\cline { 2 - 8 } & Polska & 12,68 & 24,14 & 41,51 & 39,18 & 24,09 & 27,40 \\
\hline \multirow{2}{*}{ PSL } & Gdańsk & 1,21 & 0,57 & 1,98 & 1,62 & 0,84 & 3,54 \\
\cline { 2 - 8 } & Polska & 8,98 & 6,96 & 8,91 & 8,36 & 5,13 & 8,55 \\
\hline \multirow{2}{*}{ SLD } & Gdańsk & 29,67 & 7,99 & 9,31 & 5,03 & 6,01 & 15,66 \\
\cline { 2 - 9 } & Polska & 41,04 & 11,31 & 13,15 & 8,24 & 7,55 & 12,56 \\
\hline
\end{tabular}

Źródło: Opracowanie własne na podstawie danych PKW publikowanych na www.pkw.gov.pl.

Gdańszczan pod względem swoich upodobań politycznych w wyborach do Sejmu RP cechowała zatem mało spotykana intensywność sympatii wobec Platformy. Preferencje te powinny zatem również w jakimś stopniu znaleźć swoje odzwierciedlenie w wyborach samorządowych, zarówno w rywalizacji o miejsca w radzie miasta, jak i w tej o fotel prezydenta. Wyjątkowo duże poparcie dla Platformy mogło dać tej partii wyraźną przewagę w rywalizacji lokalnej, zwłaszcza, iż w Gdańsku można było zauważyć wykrystalizowanie się specyficznej symbiozy instytucjonalno-personalnej. Miała ona dwa składniki: z jednej strony była to Platforma jako główna siła polityczna, a z drugiej - Paweł Adamowicz jako „osoba” tej partii w fotelu prezydenta. Symbioza ta wykazała się niezwykłą efektywnością aż do końca 2017 r.

Biorąc zatem pod uwagę preferencje partyjne gdańszczan można byłoby sądzić, że w wyborach lokalnych największą popularnością powinna się cieszyć Platforma, a partią najbardziej zainteresowaną w zdobywaniu przyczółków w strukturach władz lokalnych powinien być PiS. W przypadku Gdańska teza taka w zasadzie była potwierdzana przez wyniki wyborów samorządowych w latach 2002-2014, w których kandydat PO, P. Adamowicz zawsze wygrywał, a partia ta zawsze zdobywała większość bezwzględną w gdańskiej radzie. Z wyjątkiem wyborów 2002 r. główną siłą opozycyjną pozostawało ugrupowanie J. Kaczyńskiego. Szczegóły zawarto w tabeli 2.

Przed elekcją z 2018 r. ten utarty schemat z poprzednich elekcji - w Gdańsku wygrywa PO z Pawłem Adamowiczem w roli głównej - nie wydawał się już taki oczywisty. Paweł Adamowicz do piątej bezpośredniej elekcji prezydenckiej przystępował już jako kandydat niezależny, który stawał do walki o reelekcję z pretendentami silnej w Gdańsku PO i rządzącego centralnie PiS. W przypadku Gdańska elekcja AD 2018 pozwalała zatem na poszukiwanie odpowiedzi na frapujące pytanie: co jest istotniejsze dla efektywności rywalizacji o prezydenturę miasta - poparcie dominującej partii, czy raczej własne, personalne atrybuty kandydata, dzięki którym był on postrzegany jako dobry włodarz przez większość mieszkańców? 
Zestawienie wyników konkurentów P. Adamowicza w wyborach samorządowych w Gdańsku w latach 2002-2018

\begin{tabular}{|c|c|c|c|c|c|c|c|c|}
\hline \multirow{3}{*}{ Rok } & \multirow{3}{*}{ Rywal, afiliacja } & \multicolumn{4}{|c|}{ Wybory prezydenckie } & \multirow{2}{*}{\multicolumn{3}{|c|}{ Wybory do RM }} \\
\hline & & \multicolumn{2}{|c|}{ I tura } & \multicolumn{2}{|c|}{ II tura } & & & \\
\hline & & l. gl. & \% gl. & l. gl. & $\%$ gl. & l. gl. & $\%$ gl. & $\mathrm{M}=\mathbf{3 4}$ \\
\hline 2002 & Marek Formela, SLD-UP & 21473 & 17,49 & 27474 & 27,72 & 20785 & 17,20 & 6 \\
\hline 2006 & \multirow[t]{3}{*}{ Andrzej Jaworski, PiS } & 47041 & 29,67 & - & - & 44400 & 28,37 & 13 \\
\hline 2010 & & 30749 & 21,84 & - & - & 32630 & 23,41 & 7 \\
\hline 2014 & & 36736 & 26,15 & 48730 & 38,75 & 39627 & 29,41 & 12 \\
\hline 2018 & Kacper Płażyński, PiS & 62594 & 29,68 & 70432 & 35,20 & 54456 & 26,29 & 16 \\
\hline
\end{tabular}

Źródło: Opracowanie własne na podstawie danych PKW publikowanych na www.pkw.gov.pl.

\section{Specyfika wyborów w 2018 r. w Gdańsku}

Analizując gdańskie wybory z 2018 r. rodzi się oczywiste pytanie: skoro P. Adamowicz pod szyldem PO wygrywał wcześniej czterokrotnie, jego osoba nadal wzbudzała sympatie mieszkańców, a partia ta cieszyła się w Gdańsku bardzo wysokim poparciem, utrzymując wyraźną przewagę nad PiS, to dlaczego drogi tej partii i włodarza miasta rozeszły się? Przyczyny rezygnacji z podążania wspólną drogą miały charakter dość wysublimowany, co więcej, źródeł wieloletniej symbiozy personalno-instytucjonalnej w Gdańsku można dopatrywać się w problemie, który w mniejszym lub większym stopniu występuje w każdej dużej partii politycznej - wewnętrznych walkach frakcyjnych.

W gdańskiej Platformie istniały dwie frakcje, które konkurowały ze sobą o realną władzę w partii i w mieście. Jeden z polityków gdańskich tę specyfikę najsilniejszej partii trójmiejskiej opisywał następująco: „Nasza Platforma, tutaj w Gdańsku zawsze troszeczkę była taka podzielona, zawsze istniały troszeczkę takie dwa obozy, jeden był taki bardziej konserwatywny, właśnie związany ze środowiskiem pana prezydenta, powiedzmy z dawnym środowiskiem SKL, i zawsze był ten troszkę, ten bardziej liberalny - Młodzi Demokraci, jeszcze za starszych czasów to KLD, związani z nim politycy, one się tam zawsze jakoś ścierały, to było mniej lub bardziej widoczne w mieście, mniej lub bardziej widoczne medialnie" (Rozmowa nr W5dd_024c). Inny polityk obserwujący te działania dodawał: „Młodzi Demokraci to jest ... to jest w pewnym sensie... prawie sekta, tak. To są ludzie, którzy się popierają, którzy się tylko ze sobą trzymają, w określonym gronie, potem przychodzą następni, jest zmiana pokoleniowa, a oni ciągle żyją w tych swoich, takich szufladkach" (Rozmowa nr W5dd_019c). Jak się okazało punktem kulminacyjnym w rywalizacji tych frakcji była sprawa darmowych biletów komunikacji miejskiej dla młodzieży, za czym opowiadali się działacze Młodych Demokratów, a czemu sprzeciwiał się P. Adamowicz. Ostatecznie, wbrew prezydentowi partia zobowiązała radnych PO do wprowadzenia stosownej uchwały. Jeden z uczestników spotkania gremium partyjnego, na którym podejmowano stosowną decyzję polityczną, tak je wspominał: „I myślę, że to był przełom. On [P. Adamowicz] był chory wtedy, nie mógł być na tej radzie powiatu. [...] Następnego dnia zwołał konferencję prasową: że nie dość, że dla podstawówek, to jeszcze dla wszystkich do 23. roku życia, czyli jakby 
przebił to, przebił po prostu tak ohydnie, no i wtedy zaczęły się takie trochę przepychanki" (Rozmowa nr W5dd_019c).

Decyzja P. Adamowicza, co zrozumiałe, musiała doprowadzić do pogłębienia podziałów w gdańskiej PO, które dodatkowo wzmacniały stawiane prezydentowi zarzuty dotyczące legalności jego majątku. W obliczu zbliżających się wyborów partia ta musiała szybko znaleźć odpowiedź na dwa kluczowe pytania: czy w zaistniałej sytuacji wieloletni włodarz Gdańska będzie ubiegał się o kolejną reelekcję w 2018 r., oraz, bez względu na to czy odpowiedź na pierwsze pytanie będzie pozytywna czy negatywna kogo Platforma może wystawić jako swojego kandydata do tej elekcji?

Tymczasem P. Adamowicz sam odpowiedział na pierwsze pytanie: 18 II 2018 r. ogłosił, że będzie się ubiegał o kolejną kadencję prezydencką w Gdańsku. P. Adamowicz wystartował oficjalnie jako reprezentant KWW Pawła Adamowicza Wszystko dla Gdańska. Kilka dni później poseł Sławomir Neumann spotkał się z nim, próbując doprowadzić do jakiegoś kompromisu (Katka, 2018a).

Rozpatrując potencjalne możliwości w kwestii drugiej brano pod uwagę Jarosława Wałęsę, który w październiku sam siebie zarekomendował, mówiąc: „Gdańskowi przydałoby się nowe, świeże spojrzenie, ciekawe pomysły [...] Prezydent Adamowicz powinien zrozumieć, że po tylu latach, z tak olbrzymim doświadczeniem, mógłby spróbować swoich sił w innych miejscach" (Katka, 2017). Zarazem rozważano kandydaturę Agnieszki Pomaski, która miała istotne poparcie w szeregach partii w Trójmieście (Rozmowa nr W5dd_019c). Według wewnętrznych badań prowadzonych przez PO wiosną 2018 r. J. Wałęsa miał rozpoznawalność na poziomie 60-70 proc. (Rozmowa nr W5dd_024c), ale oficjalnie zgłoszono go dopiero pod koniec czerwca. Jego nominacja do startu w wyborach spotkała się jednak z oporem działaczy gdańskiej Platformy, gdyż uznawano ją za zgłoszoną de facto przez Grzegorza Schetynę. Co więcej, J. Wałęsie zarzucano brak zaangażowania i umiejętności potrzebnych w kampanii wyborczej (Rozmowa nr W5dd_018e; Rozmowa nr W5dd_024c).

Politycy PiS również stosunkowo długo zastanawiali się nad wyborem swojego pretendenta do fotela prezydenta Gdańska w wyborach 2018 r. Ostatecznie kierownictwo tej partii zgłosiło 26 IV 2018 r. Kacpra Płażyńskiego, o czym miały ostatecznie zdecydować badania społeczne, wedle których K. Płażyński cieszył się dobrą rozpoznawalnością, a ponadto przewidywano, iż będzie mógł poszerzyć elektorat PiS (Sandecki, 2018a).

W toku rywalizacji przedwyborczej okazało się, że P. Adamowicz i K. Płażyński prowadzili niezwykle intensywną i wizerunkowo sprawną kampanię wyborczą, podczas gdy J. Wałęsa nie potrafił dorównać tempu prowadzonej przez nich kampanii.

Istotne znaczenie miała również próba przeniesienia ogólnopolskiego konfliktu anty-PiS vs. PiS. Jeden z polityków lokalnych zauważał: „,moim zdaniem nawet w PO niewykonalne było żeby zwiększyć frekwencje itd. Natomiast wiadomo, że musiały być duże emocje, jeśli taka frekwencja się pojawiła, i musiało to być, nie wiem, tak kolokwialnie powiem, z nienawiści do PiS" (Rozmowa nr W5dd_018e). Inny działacz opisywał ten problem następująco: „te ostatnie wybory tak jak mówię - no to nie jest tylko obserwacja Gdańska, ale tak szerzej w całym kraju, to już był taki absolutnie plebiscyt, trochę PiS anty-PiS. No i tutaj po prostu pan prezydent Adamowicz zarówno przez swoje doświadczenie, ale też przez swoje różnego rodzaju polityczne działania ... był bardzo wiarygodnym takim przedstawicielem anty-PiS-u. [...] Adamowicz był lepszy w konkursie na 
bycie anty-PiS-em. Był - tak, zdecydowanie lepszy, tak. Jego dotychczasowe działania, ale także działania w kampanii wyborczej pokazywały, że ogniskuje wokół siebie ten elektorat" (Rozmowa nr W5dd_024c). Wspominano w tym kontekście, że P. Adamowicz „wyrósł też na takiego człowieka, który jest taką ikoną, no ikona to może za dużo, ale takim trochę symbolem wojującego prezydenta” (Rozmowa nr W5dd_019c).

Strategia PO nastawiona na podgrzewanie dychotomii any-PiS-PiS nie mogła przynieść efektów dla tej partii, ponieważ zastosował ją również konkurent tej partii, czyli P. Adamowicz. Zastosowanie przez dwóch konkurencyjnych względem siebie rywali tej samej strategii (J. Wałęsa i P. Adamowicz) - prowadzić musiało do wewnętrznej rywalizacji pomiędzy nimi o miano lidera opcji anty-PiS w Gdańsku.

Przed wyborami przeprowadzono wiele sondaży wyborczych, które pokazywały silną pozycję P. Adamowicza i słabnącą - J. Wałęsy. Przykładowo w realizowanym od 6 do 12 X 2018 r. poparcie dla pierwszej trójki było następujące: P. Adamowicz - 30 proc., J. Wałęsa - 26 proc., K. Płażyński - 23 proc. Kolejne wskazania otrzymali: Jacek Hołubowski (Gdańsk Tworzą Mieszkańcy - 1 proc.), Elżbieta Jachlewska (Lepszy Gdańsk - 1 proc.), Andrzej Ceynowa (SLD - 1 proc.), Dorota Maksymowicz-Czapkowska (Narodowy Front Polski - 0 proc.) Choć badanie to przeprowadzono metodą CATI (miks tel. komórkowych i stacjonarnych), to warto zwrócić uwagę na dwie istotne grupy respondentów: „niezdecydowani” - 14 proc., oraz „odmowa odpowiedzi” - 4 proc. Ponadto badanie realizowano $\mathrm{w}$ trakcie dwóch potyczek sądowych pomiędzy P. Adamowiczem a K. Płażyńskim: pierwszą wygrał (nieprawomocnie) kandydat PiS, a drugą, prawomocnie - urzędujący prezydent (Katka, 2018b). Z kolei wedle opublikowanego kilkadziesiąt godzin przed wyborami sondażu dla TVP pojawiła się już inna kolejność: P. Adamowicz (30,9 proc.), K. Płażyński (26,2 proc.), J. Wałęsa (25 proc.), E. Jachlewska (Lepszy Gdańsk - 9,5 proc.), J. Hołubowski (Gdańsk Tworzą Mieszkańcy - 3,6 proc.), A. Ceynowa (SLD Lewica Razem - 2 proc.), D. Maksymowicz-Czapkowska (Narodowy Front Polski - 2 proc.) (Sandecki, 2018b).

Rezultaty I tury wyborów prezydenckich ( 21 X 2018 r.) w odniesieniu do pierwszej trójki były zbieżne z tym ostatnim wskazaniem. Na P. Adamowicza zagłosowało 77966 wyborców, K. Płażyński dostał 62594 głosy, a J. Wałęsa - 58 561. Szczegółowe wyniki personalne i komitetów wyborczych zaprezentowano w tabeli 4.

Tabela 4

Wyniki wyborów w Gdańsku w 2018 r.

\begin{tabular}{|c|c|c|c|c|c|c|c|c|}
\hline \multirow{3}{*}{ Listy wyborcze } & \multicolumn{5}{|c|}{ Wybory prezydenckie } & \multirow{2}{*}{\multicolumn{3}{|c|}{ Wybory do RM }} \\
\hline & \multicolumn{3}{|c|}{ I tura } & \multicolumn{2}{|c|}{ II tura } & & & \\
\hline & kandydat & l. gl. & \% gl. & l. gl. & $\%$ gl. & l. gl. & \% gl. & $M=34$ \\
\hline 1 & 2 & 3 & 4 & 5 & 6 & 7 & 8 & 9 \\
\hline $\begin{array}{l}\text { KKW SLD Lewica Ra- } \\
\text { zem }\end{array}$ & Andrzej Ceynowa & 2036 & 0,97 & & & 6330 & 3,06 & - \\
\hline KKW PNKO & Jarosław Wałęsa & 58561 & 27,77 & & & 81370 & 39,29 & 16 \\
\hline KW PiS & Kacper Plażyński & 62594 & 29,68 & 70432 & 35,20 & 54456 & 26,29 & 12 \\
\hline KW Wolni i Solidarni & - & & & & & 239 & 0,12 & - \\
\hline $\begin{array}{l}\text { KWW Gdańsk Tworzą } \\
\text { Mieszkańcy }\end{array}$ & Jacek Hołubowski & 4170 & 1,98 & & & 13424 & 6,48 & - \\
\hline $\begin{array}{l}\text { KWW Ruch Społeczny } \\
\text { Lepszy Gdańsk }\end{array}$ & $\begin{array}{l}\text { Elżbieta Jachlew- } \\
\text { ska }\end{array}$ & 4146 & 1,97 & & & 10727 & 5,18 & - \\
\hline
\end{tabular}




\begin{tabular}{|l|l|c|c|c|c|c|c|c||}
\hline \multicolumn{1}{|c|}{1} & \multicolumn{1}{|c|}{2} & 3 & 4 & 5 & 6 & 7 & 8 & 9 \\
\hline $\begin{array}{l}\text { KWW Narodowego } \\
\text { Frontu Polskiego } \\
- \text { W. Olszańskiego }\end{array}$ & $\begin{array}{l}\text { Dorota Maksymo- } \\
\text { wicz-Czapkowska }\end{array}$ & 1427 & 0,68 & & & 959 & 0,46 & - \\
\hline $\begin{array}{l}\text { KWW Adamo- } \\
\begin{array}{l}\text { Pawła Adamowicza } \\
\text { Wszystko dla Gdańska }\end{array}\end{array}$ & $\begin{array}{l}\text { Pawel } \\
\text { wicz }\end{array}$ & 366 & 36,97 & 129683 & 64,80 & 39612 & 19,13 & 6 \\
\hline
\end{tabular}

Źródło: Opracowanie własne na podstawie danych PKW publikowanych na www.pkw.gov.pl.

I tura wyborów prezydenckich pokazała więc, że górę wzięły personalne atrybuty inkumbenta nad magią popularnej w Trójmieście partii. Jak się okazało duża część elektoratu PO zagłosowała na włodarza Gdańska, a nie na kandydata tej partii, który, cokolwiek by mówić, miał przecież również bardzo rozpoznawalne nazwisko. W tabeli 5 zawarto wyliczenia wskaźników: związku z zapleczem (WZ), intensyfikacji rywalizacji wyborczej między P. Adamowiczem i J. Wałęsą (WR) oraz intensyfikacji rywalizacji wyborczej pomiędzy komitetem P. Adamowicza a komitetem J. Wałęsy (WR1K). Wartości te pokazują pozycję dwóch rywali walczących o ten sam elektorat.

Tabela 5

Gdańsk 2018 r.: wskaźniki rywalizacji pomiędzy zwycięzcą wyborów prezydenckich P. Adamowiczem a jego rywalem z PNKO J. Walęsą (WR1), ich komitetami (WR1K) oraz związku kandydatów z wlasnymi zapleczem (WZ)

\begin{tabular}{|c|l|l|c|c|c||}
\hline Lp. & \multicolumn{1}{|c|}{ Gdańsk 2018 } & \multicolumn{1}{|c|}{ komitet } & WZ & \multirow{2}{*}{ WR1 } & \multirow{2}{*}{ WR1K } \\
\hline 1. & Paweł Adamowicz & WdG & 1,93 & \multirow{2}{*}{9,2} & \multirow{2}{*}{$-20,16$} \\
\hline 2. & Jarosław Wałęsa & PNKO & 0,71 & & \\
\hline
\end{tabular}

Źródło: Obliczenia własne na podstawie danych PKW.

Na podstawie powyższych wartości można dostrzec, iż P. Adamowicz miał w $2018 \mathrm{r}$. największy przyrost wyborców spoza elektoratu własnego komitetu. Wartość jego WZ wyniosła bowiem aż 1,93 , podczas gdy u J. Wałęsy osiągnęła ona zaledwie 0,71 . Co oczywiste, PO odniosła spory sukces w wyborach radnych, otrzymując 39,12 proc. głosów, ale zarazem odczuła konsekwencje nielojalności jej elektoratu w elekcji prezydenckiej: prawie 23 tys. głosujących na kandydatów PO do rady miasta nie wskazało J. Wałęsy w elekcji prezydenckiej. Zważywszy na fakt, że elektorat PO generalnie nie głosuje na PiS, a inni kontrkandydaci uzyskali znikome poparcie (żaden z nich nie przekroczył 2 proc., a kandydat SLD nie osiągnął nawet poziomu 1 proc.), to przepływ elektoratu głosującego na PO w wyborach do RM na rzecz P. Adamowicza w wyborach prezydenckich wydaje się po prostu najbardziej oczywisty. Wskaźniki WZ J. Wałęsy i P. Adamowicza są zarazem dobrym odniesieniem do znalezienia odpowiedzi na pytanie: co było w elekcji prezydenta Gdańska w 2018 r. istotniejsze, jej upartyjnienie czy personalizacja? Skoro pretendenta PO popierała znacznie mniejsza liczba wyborców niż komitet tworzony przez PO w rywalizacji o mandaty radnych, to wyraźnie widać, iż magia silnej pozycji PO w Gdańsku nie zadziałała w elekcji J. Wałęsy. Z drugiej strony, skoro bezpartyjny, ale zarazem eks-partyjny (,eks-platformerski”) w 2018 r. P. Adamowicz skupił na sobie znacząco większe poparcie niż jego komitet (Wszystko dla Gdańska) w batalii o miejsca w gdańskiej radzie, to przy- 
czyn tego stanu należy upatrywać $\mathrm{w}$ atrybutach personalnych tego inkumbenta, którego tym samym można było określać mianem nie tylko wielokadencyjnego, ale i ,wiecznego prezydenta" (szerzej: np. Drzonek, 2019b, s. 127-128).

W przypadku K. Płażyńskiego - wskaźnik WZ przekroczył pułap 1,0. Pretendent PiS zatem spełnił pokładane w nim nadzieje liderów tej partii sprzed kampanii i pozyskał także tych wyborców, którzy nie zagłosowali na kandydatów tego ugrupowania do rady miasta $^{2}$. W tabeli 6 zaprezentowano wskaźniki WZ, WR i WR1K kandydata PiS w relacji do indykatorów P. Adamowicza.

Tabela 6

Gdańsk 2018 r.: wskaźniki rywalizacji pomiędzy zwycięzcą wyborów prezydenckich P. Adamowiczem a jego rywalem z PiS K. Plażyńskim (WR1), ich komitetami (WR1K) oraz związku kandydatów z własnymi zapleczem (WZ)

\begin{tabular}{|r|l|c|c|c|c||}
\hline Lp. & Gdańsk 2018 & Komitet & WZ & WR1 & WR1K \\
\cline { 1 - 3 } 1. & Paweł Adamowicz & WdG & 1,93 & \multirow{2}{*}{7,29} & $-7,16$ \\
\hline 2. & Kacper Płażyński & PiS & 1,13 & & \\
\hline
\end{tabular}

Źródło: Obliczenia własne na podstawie danych PKW.

\section{Zakończenie}

W przypadku Gdańska teza o słabości partii w zdobywaniu władzy okazała się więc co najmniej połowicznie potwierdzona: PO przegrała w rywalizacji o stanowisko prezydenta, czyli o główne narzędzie sprawowania władzy w mieście. Zarazem jednak Platforma, zdobywając 16 mandatów radnych, w zasadzie zapewniła sobie współudział w sprawowaniu władzy. PiS z kolei, dzięki skutecznej kampanii K. Płażyńskiego pokonał PO w rywalizacji prezydenckiej oraz pokazał, iż może poszerzać swój elektorat w mieście, w którym dominują preferencje na rzecz PO.

Odpowiedź na pytanie o personalizację i upartyjnienie rywalizacji stała się bardziej wysublimowana. Generalnie zatem zdecydowane zwycięstwo P. Adamowicza w rywalizacji o prezydenturę miasta potwierdziło hipotezę o przewadze opcji personalnej nad partyjną: dla wyborców ważniejsze okazały się osobiste cechy P. Adamowicza niż nimb dominującej w Gdańsku opcji partyjnej. Dobrze obrazowała to wypowiedź jednego z respondentów, który zwrócił uwagę na paradoks efektów rywalizacji wyborczej o gdańską prezydenturę w 2018 r: ,prezydent, który odciął się od swego zaplecza - wygrał” (Rozmowa nr x5ww_054h). Inny z respondentów również zdawał się wskazywać na osobiste cechy inkumbenta, a nie jego afiliację partyjną mówiąc, że „ludzie często głosują na tego samego prezydenta, jak Adamowicz w Gdańsku, bo może być faktycznie dobrym przywódcą" (Rozmowa nr W1xs_012b). Choć pojawiło się także przypuszczenie, że źródłem sukcesu mogło być zbudowanie ,sieci potężnego poparcia również członków

${ }^{2}$ K. Płażyński zebrał o nieco ponad 8 tys. głosów więcej, niż lista PiS do rady. Warto także odnotować, że - to też świadczy o jego osobistej popularności - startując do rady miasta uzyskał najlepszy wynik spośród wszystkich kandydatów z 2018 r. (na radnego Płażyńskiego zagłosowało 9794 wyborców, a na radnego P. Adamowicza - 5599. Z kolei J. Wałęsa nie wyraził zainteresowania jednoczesnym ubieganiem się o mandat radnego). 
takiej partii jak PO, którzy stanęli za nim [P. Adamowiczem], a nie za Wałęsą" (Rozmowa nr W1ds_020h).

Przypadek gdańskiej rywalizacji w 2018 r., w odniesieniu do walki o prezydenturę, pozwolił bowiem twierdząco odpowiedzieć na zadane na początku rozważań dwa pierwsze pytania: pomimo dominujących preferencji na rzecz Platformy sukces w walce o reelekcję osiągnął P. Adamowicz, mimo, że kandydował przeciw kandydatowi tej partii (J. Wałęsa), wcześniej samemu będąc wieloletnim włodarzem miasta z ramienia Platformy.

Odnosząc się do trzeciego pytania zawartego na początku rozważań należy zauważyć, że rywalizujące w Gdańsku partie polityczne próbowały zastosować ogólnopolski podział anty-PiS vs. PiS, czyli swoistą, nową emanację podziału „my kontra oni”. Wprowadzenie do lokalnej rywalizacji tej strategii nie przyniosło partiom efektywności, choć z różnych powodów. W Gdańsku przyczyna braku efektywności tej strategii leżała w specyfice struktury rywalizacji lokalnej w 2018 r. W walce o władzę lokalną pojawiły się tam bowiem dwie drużyny anty-PiS (PO i komitet P. Adamowicza) przeciw jednej drużynie PiS. Najbardziej prawdopodobne było więc osiągnięcie sukcesu przez jedną z drużyn anty-PiS, a nie obydwie. W konsekwencji jedna z drużyn anty-PiS wygrała w wyborach prezydenckich (P. Adamowicz), zwłaszcza, że jak wyżej zauważono, w rywalizacji tej ważniejsze były atrybuty personalne, a nie - partyjne. Natomiast w wyborach do rady w Gdańsku wygrała druga drużyna anty-PiS (PO jako PNKO), bo tam bardziej liczyło się upartyjnienie tej rywalizacji.

\section{Bibliografia}

Antkowiak P., Scheffs Ł. (2015), Teoria i praktyka przywództwa politycznego. Na przykładzie bezpośrednich wyborów wójta, burmistrza i prezydenta miasta, Wydawnictwo Naukowe WPID UAM, Poznań.

Bartkowski W. (2003), Identyfikacja partyjna w przestrzennej teorii wyborów, „Studia Socjologiczne”, nr 1 (168).

Bukowski M., Flis J., Hess A., Szymańska A. (2011), Opcja czy osoba? Upartyjnienie versus personalizacja w wyborach samorząowych, WUJ, Kraków.

Delwit P., Pilet J.-B., Reynaert H., Steyvers K. (eds.) (2009), Local political leadership in Europe: town chief, city boss or loco president?, Vanden Broele, Brugge.

Drzonek M. (2016), Preferencje polityczne wśród kandydatów na radnych. Przypadek wyborów w Szczecinie w 2014 r., w: Polityka Lokalnie. Kampania i wybory samorzadowe 2014, red. M. Drzonek, K. Oświecimski, A. Wołek, Wydawnictwo WAM, Akademia Ignatianum w Krakowie, Kraków.

Drzonek M. (red.) (2014), Partyjnie czy bezpartyjnie? Szkice o zdobywanie władzy lokalnej, WNUS, Szczecin.

Drzonek M. (2019a), Im dlużej tym „, bezpartyjniej”? Włodarze dużch miast w wyborach 2002-2018, „Przegląd Politologiczny”, nr 2.

Drzonek M. (2019b), Wieczni prezydenci. Dwa przypadki trójmiejskie, Ośrodek Myśli Politycznej, Kraków 2019.

Elmelund-Præstekær C., Kjaer U. (2013), Presidentialisation of parliamentary systems? Frontrunner concentration in Danish local elections, "Representation", $\mathrm{nr} 2$ (49).

Flis J., Gendźwiłł A., Stolicki D. (2018), Rywale włodarzy. Doświadczenia i szanse samorzadowych pretendentów, „e-Politikon”, $\mathrm{nr} 26$. 
Gendźwiłł A. (2013), Why do Poles (still) Dislike Political Parties? Some Survey Insights into AntiParty Attitudes in Poland, 1995-2011, "Polish Sociological Review", nr 4 (184).

Gendźwiłł A., Żółtak T. (2014), Why Do Non-partisans Challenge Parties in Local Politics?, „EuropeAsia Studies", vol. 66.

Jacobsen D. I., Skollevold A. S. (2016), Presidentialisation on the executive arena at the local level? The case of Norway 1992-2012, „Zarządzanie Publiczne”, nr 1 (35).

Katka K. (2018a), Paweł Adamowicz: Startuję na prezydenta Gdańska. Z Platforma lub bez niej, http:// wyborcza.p1/7,75398,23044336,pawel-adamowicz-startuje-na-prezydenta-gdanska-z-platforma.html, 19.02.2018.

Katka K. (2018b), Przełom w kampanii wyborczej w Gdańsku. Sondaż prezydencki Wyborczej, http:// trojmiasto.wyborcza.pl/trojmiasto/7,35612,24043208,przelom-w-kampanii-wyborczej-w-gdansku-sondaz-prezydencki-wyborczej.html, 15.10.2018.

Katka K. (2017), Jarosław Wałęsa chce zostać prezydentem. „,Koniec z Bruksela, wracam do Gdańska”, http://trojmiasto.wyborcza.pl/trojmiasto/7,35612,22540575, jaroslaw-walesa-chce-zostac-prezydentem-koniec-z-bruksela.html, 22.10.2017.

Kowalczyk K. (2014), Prezydencjalizacja wyborów samorządowych w Szczecinie w 2010 r., w: Partyjnie czy bezpartyjnie? Szkice o zdobywaniu władzy lokalnej, red. M. Drzonek, WNUS, Szczecin.

Mancini P. (2011), Leader, president, person: Lexical ambiguities and interpretive implications, „European Journal of Communication", nr 26.

Peszyński W. (2016), Prezydencjalizacja zachowań wyborczych w elekcji parlamentarnej w 2015 roku, „Political Preferences”, nr 12.

Peszyński W. (2012), Zjawisko prezydencjalizacji kampanii samorzadowych. Przykład wyborów 2010 roku w województwie kujawsko-pomorskim, w: Media i marketing polityczny, red. M. Jeziński, W. Peszyński, A. Seklecka, Toruń.

Poguntke T., Webb P. (2005), The presidentialization of politics in democratic societies: A framework for analysis, w: The presidentialization of politics: a comparative study of modern democracies, red. T. Poguntke, P. Webb, Oxford University Press, Oxford.

Poguntke T., Webb P. (2013), The presidentialisation of politics thesis defended, "Parliamentary Affairs" nr 66 (3).

Reynaert H., Steyvers K., Delwit P., Pilet J.-B. (red.) (2005), Revolution or renovation? Reforming local politics in Europe, Vanden Broele, Brugge.

Rozmowa nr W1ds_020h.

Rozmowa nr W1xs_012b.

Rozmowa nr W5dd_018e.

Rozmowa nr W5dd_019c.

Rozmowa nr W5dd_024c.

Rozmowa nr x5ww_054h.

Sandecki M. (2018a), ,, Grzeczny ,pistolet’ z propaństwowa postawa”. Politycy komentuja kandydaturę Kacpra Płażyńskiego na prezydenta Gdańska, http://trojmiasto.wyborcza.pl/trojmiasto/7,35612,23327116, grzeczny-pistolet-z-propanstwowa-postawa-politycy-komentuja.html, 26.04.2018.

Sandecki M. (2018b), Sensacyjny sondaż TVP dla Gdańska. W drugiej turze Adamowicz i Płażyński, http://trojmiasto.wyborcza.pl/trojmiasto/7,35612,24064628, sensacyjny-sondaz-tvp-dla-gdanska-w-drugiej-turze-adamowicz.html, 19.10.2018.

Szczepański D. (2016), Upartyjnienie versus personalizacja jako czynniki determinujace zachowania wyborcze w krajowych elekcjach w 2015 roku, „Political Preferences”, nr 12.

Wattenberg M. P. (1991), The Rise of Candidate-Centered Politics: Presidential Elections of the 1980s, Cambridge. 


\title{
Local power not for the political parties? The case of Pawel Adamowicz in the 2018 local competition
}

\begin{abstract}
Summary
The subject of the research undertaken in the article is the competition for local authority in Gdańsk in 2018. In the previous elections (the years: 2002, 2006, 2010, 2014) the presidency of the city were permanently won by Paweł Adamowicz. He always officially represented the very popular political party in Gdańsk - Platforma Obywatelska (PO). In 2018, however, Adamowicz started from his own committee (KWW Paweł Adamowicz Wszystko dla Gdańska - Everything for Gdańsk). In that year he competed for the chair of the city president with both the candidate of the PO (Jarosław Wałęsa) and the Prawo i Sprawiedliwość (PiS) candidate (Kacper Płażyński). The 2018 elections in Gdańsk were therefore an interesting casus: "the same" Pawel Adamowicz joined the fight, but already as a representative of his own nonpartisan committee. Moreover, he stood against the party he had earlier always represented. So it was an interesting case to seek the answer to the question - what will become the prevailing element in this competition: its partisan affiliation or personalization? Secondly, it was fascinating to check whether the transfer of the dominant nationwide division (the former "my-oni" division, and in the 2018 version: antyPiS vs. PiS) brings political parties effectiveness in the competition for local power? The following assumptions were made: a. The personal option is more important in competing for local authority than party sympathies; b. the new version of the division "my-oni" (PiS-antyPiS) does not bring effectiveness in the struggle for power on Gdańsk political scene. The value of the research is to use not only published sources but also unpublished qualitative research - anonymous interviews with local politicians.
\end{abstract}

Key words: local power, political parties, personalization of local elections, Paweł Adamowicz, political competition, Gdańsk 
